\title{
HARVEST TIMES WITH CHEMICAL DESICCATION AND THE EFFECTS ON THE ENZYMATIC EXPRESSION AND PHYSIOLOGICAL QUALITY OF SOYBEAN SEEDS ${ }^{1}$
}

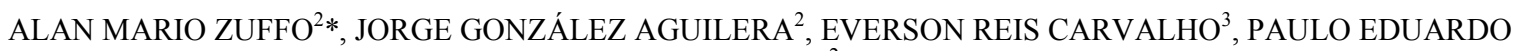 \\ TEODORO $^{2}$
}

\begin{abstract}
This study aimed to evaluate the effect of chemical desiccants and harvest times on the enzymatic expression and physiological quality of soybean seeds. The experiment was carried out in a randomized block design with four replications, in a factorial scheme $(4 \times 3+1)$ with four desiccants (paraquat - $2 \mathrm{~L} \mathrm{ha}^{-1}$, ammonium glufosinate $-2 \mathrm{~L} \mathrm{ha}^{-1}$, diquat $-1.5 \mathrm{~L} \mathrm{ha}^{-1}$, and saflufenacil - $40 \mathrm{~g} \mathrm{ha}^{-1}$ ). These were applied at the phenological stage $\mathrm{R}_{7.1}$ (beginning of leaf yellowing) and at three harvest times $(0,14$, and 28 days after the phenological stage $\mathrm{R}_{8}$ ). There was also a control treatment (no desiccant, harvested at $\mathrm{R}_{8}$ ). The physiological quality of soybean seeds and the enzymatic expressions of malate dehydrogenase, alcohol dehydrogenase, esterase, isocitrate lyase, and superoxide dismutase were evaluated in laboratory tests. Seeds harvested at the $\mathrm{R}_{8}+14$ stage led to the highest losses in seed quality. However, the $50 \mathrm{~mm}$ rainfall also affected seed deterioration. The desiccants diquat and paraquat provided the lowest and the highest damage to the seed physiological quality, respectively. The expression of the enzymes alcohol dehydrogenase, esterase, and isocitrate lyase were efficient and had an adequate correlation with the physiological quality. Malate dehydrogenase and superoxide dismutase had no satisfactory relation with the physiological tests performed with soybean seeds.
\end{abstract}

Keywords: Antioxidants. Glycine max. Physiological maturation. Respiration processes.

\section{EPÓCAS DE COLHEITA COM DESSECAÇÃO QUÍMICA E SUAS RELAÇÕES COM A QUALIDADE FISIOLÓGICA E EXPRESSÃO ENZIMÁTICA EM SEMENTES DE SOJA}

\begin{abstract}
RESUMO - O objetivo no trabalho foi avaliar o efeito de dessecantes químicos e épocas de colheita sobre a qualidade fisiológica e expressão enzimática em sementes de soja. O delineamento experimental foi blocos casualizados, com quatro repetições, em esquema fatorial $(4 \times 3+1)$ : quatro dessecantes (paraquat $-2 \mathrm{~L} \mathrm{ha}^{-1}$, glufosinato de amônio - $2 \mathrm{~L} \mathrm{ha}^{-1}$, diquat - 1,5 $\mathrm{L} \mathrm{ha}^{-1}$, saflufenacil $40 \mathrm{~g} \mathrm{ha}^{-1}$ ) aplicado no estádio fenológico $\mathrm{R}_{7.1}$ (início do amarelecimento das folhas), com três épocas de colheita $(0 ; 14$ e 28 dias após o estádio fenológico $\mathrm{R}_{8}$ ) mais o controle (ausência de dessecante e colhida em $\mathrm{R}_{8}$ ). Foi avaliada a qualidade fisiológica das sementes de soja por meio de testes em laboratório e a expressão enzimática das enzimas malato desidrogenase, álcool desidrogenase, esterase, isocitrato liase e para a superóxido dismutase. A colheita de sementes no estádio $\mathrm{R}_{8}+14$ promove as maiores perdas na qualidade das sementes, todavia, não só tempo de atraso afeta, mas a ocorrência de precipitações é decisiva, sendo que chuva de $50 \mathrm{~mm}$, já proporciona deterioração das sementes de soja. Os dessecantes diquat e paraquat foram os que promoveram os menores e maiores danos à qualidade fisiológica das sementes, respectivamente. A expressão das enzimas álcool desidrogenase, esterase e isocitrato liase são eficientes no monitoramento e com adequada correlação com a qualidade fisiológica. A malato desidrogenase e superóxido dismutase apresentam baixa correlação com os testes físiológicos realizados nas sementes de soja.
\end{abstract}

Palavras-chave: Antioxidantes. Glycine max. Maturidade fisiológica. Processos de respiração.

\footnotetext{
*Corresponding author

${ }^{1}$ Received for publication in 08/20/2019; accepted in 02/05/2020.

${ }^{2}$ Department of Agronomy, Universidade Federal de Mato Grosso do Sul, Chapadão do Sul, MS, Brazil; alan_zuffo@hotmail.com ORCID: 0000-0001-9704-5325, j51173@yahoo.com - ORCID: 0000-0002-7308-0967, eduteodoro@hotmail.com - ORCID: 0000-00028236-542X.

${ }^{3}$ Department of Agriculture, Universidade Federal de Lavras, Lavras, MG, Brazil; eversoncarvalho@ufla.br - ORCID: 0000-0003-49254100 .
} 


\section{INTRODUCTION}

Soybean (Glycine max L. Merrill) is one of the most important oilseeds worldwide. Brazil is the second largest producer, with a cultivated area of 35.8 million hectares (ha), and a total yield of 115 million tons $(\mathrm{T})$ in the $2018 / 2019$ crop season (CONAB, 2020).

Soybean seed quality can be determinant in the expansion of current markets and depends on the field management and the ability of the producer to deal with biotic and abiotic stresses that affect the crop. The vigor and germination of soybean seeds is influenced by the genetics of the crop, the environment, and agricultural practices, among other factors (MOREANO et al., 2013). Seed quality is related to the moisture content in the seed when it gets close to the harvest time. Physiologically, when the seed is near to its maturation, the water content naturally decreases, or artificially decreases when we apply desiccants to the plants to homogenize the crop and thus affect the moisture content of the seeds (MOREANO et al., 2013). The use of desiccants and the selection of the best harvest times are determinant factors at this stage (LIMA et al., 2007).

Harvest time is considered critical in the soybean production process. Studies have reported that late harvest can expose the seeds to unfavorable conditions, accelerating the deterioration process and contributing to the occurrence of diseases and damage at this stage (GRIS et al., 2010; DINIZ et al., 2013; XAVIER et al., 2015; ZUFFO et al., 2017b).
Desiccant herbicide molecules are continually evolving. Therefore, the effect of the use these molecules in several circumstances has to be evaluated to obtain a high physiological quality (KAPPES et al., 2009; DALTRO et al., 2010; BOTELHO et al., 2016). Desiccants provide faster drying and loss of leaves, besides promoting seeds water loss, which allows harvesting the seeds when they are closer to physiological maturity. Thus, this study aimed to evaluate the effect of different chemical desiccant molecules and harvest times after desiccation on the enzymatic expression and physiological quality in soybean seeds.

\section{MATERIAL AND METHODS}

\section{Experimental conditions}

The experiment was carried out at the Center for Scientific and Technological Development in Agriculture - Muquém Farm/Federal University of Lavras (UFLA), located in the municipality of Lavras, state of Minas Gerais, Brazil (lat. $21^{\circ} 14^{\prime} \mathrm{S}$, long. $45^{\circ} 00^{\prime} \mathrm{W}$, alt. 918 masl) at the Seed Central Laboratory of the Department of Agriculture of the Federal University of Lavras, MG. The soil of the experimental area is classified as a Typic Dystropherric Red Latosol (Oxisol) (EMBRAPA, 2013). The chemical and physical composition of the soil is shown in (Table 1).

Table 1. Chemical and physical composition of the Typic Dystropherric Red Latosol soil $(0-0.20 \mathrm{~m})$ before the experiment installation. Lavras - MG, in the 2013/2014 agricultural year.

\begin{tabular}{|c|c|c|c|c|c|c|c|c|c|c|}
\hline $\mathrm{pH}$ & $\mathrm{Ca}^{2+}$ & $\mathrm{Mg}^{2+}$ & $\mathrm{Al}^{3+}$ & $\mathrm{H}^{+}+\mathrm{Al}^{3+}$ & SB & CEC & $P$ & K & $\mathrm{OM}$ & V \\
\hline $\mathrm{H}_{2} \mathrm{O}$ & \multicolumn{6}{|c|}{$-\ldots-\cdots-\mathrm{cmol}_{\mathrm{c}} \mathrm{dm}^{-3}-\ldots-\ldots$} & \multicolumn{2}{|c|}{$--\mathrm{mg} \mathrm{dm}^{-3}--$} & $\mathrm{Dag} \mathrm{kg}^{-1}$ & $\%$ \\
\hline 6.4 & 5.0 & 1.4 & 0 & 2.9 & 6.7 & 9.6 & 11.46 & 118 & 3.41 & 69.82 \\
\hline \multirow[t]{2}{*}{$\mathrm{Zn}$} & $\mathrm{Mn}$ & $\mathrm{Cu}$ & $\mathrm{B}$ & $\mathrm{Fe}$ & S & Clay & Silt & Sand & \multicolumn{2}{|c|}{ Textural Class } \\
\hline & \multicolumn{6}{|c|}{ 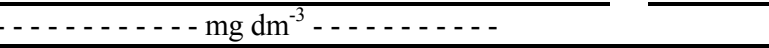 } & dag $\mathrm{kg}^{-1}$ & & \multicolumn{2}{|c|}{$-\cdots$} \\
\hline 4.97 & 31.70 & 1.40 & 0.17 & 34.81 & 4.75 & 64 & 20 & 16 & & \\
\hline
\end{tabular}

$\mathrm{H}+\mathrm{Al}$ : potential acidity; SB: sum of bases; CEC: cation exchange capacity at the $\mathrm{pH}$ 7.0; OM: organic matter; V: bases saturation.

The climate is classified as a Cwa type, according to the Köppen's classification. (Figure 1a) shows the climate data collected at the meteorological station of the National Institute of Meteorology (INMET) located at the Federal University of Lavras-UFLA, during the seed production process. (Figure $1 \mathrm{~b}$ ) specifies the conditions of the seed collection period.

This work used the soybean cultivar 'BRS $820 \mathrm{RR}^{\circledR}$, with a seeding density of 12 plants per linear meter, totaling a population density of 240,000 plants $\mathrm{ha}^{-1}$. Seeds were sown on November 15 and had been previously treated with pyraclostrobin + methyl thiophanate + fipronil $\left(\right.$ Standak Top $\left.{ }^{\circledR}\right)$, at the dose of $2 \mathrm{~mL} \mathrm{~kg}^{-1}$ of seed and inoculated with Bradyrhizobium japonicum (Nitragin Cell Tech ${ }^{\circledR}$ ), at the dose of $3 \mathrm{~mL}$ p. c. $\mathrm{kg}^{-1}$ of seed (strains SEMIA 5079 and 5080). The fertilization consisted of $350 \mathrm{~kg}$ $\mathrm{ha}^{-1}$ of $\mathrm{N}-\mathrm{P}_{2} \mathrm{O}_{5}-\mathrm{K}_{2} \mathrm{O}$ (02-30-20), applied in the furrow. Each plot had four 5-m rows, spaced at 0.50 $\mathrm{m}$ apart. The two central rows were considered the useful area after scraping 1 meter from each end. Glyphosate, pyraclostrobin + epoxiconazole, azoxystrobin + cyproconazole, diflubenzuron, chlorpyrifos, and cypermethrin were applied during the plant's development for weed, pest, and disease control. 

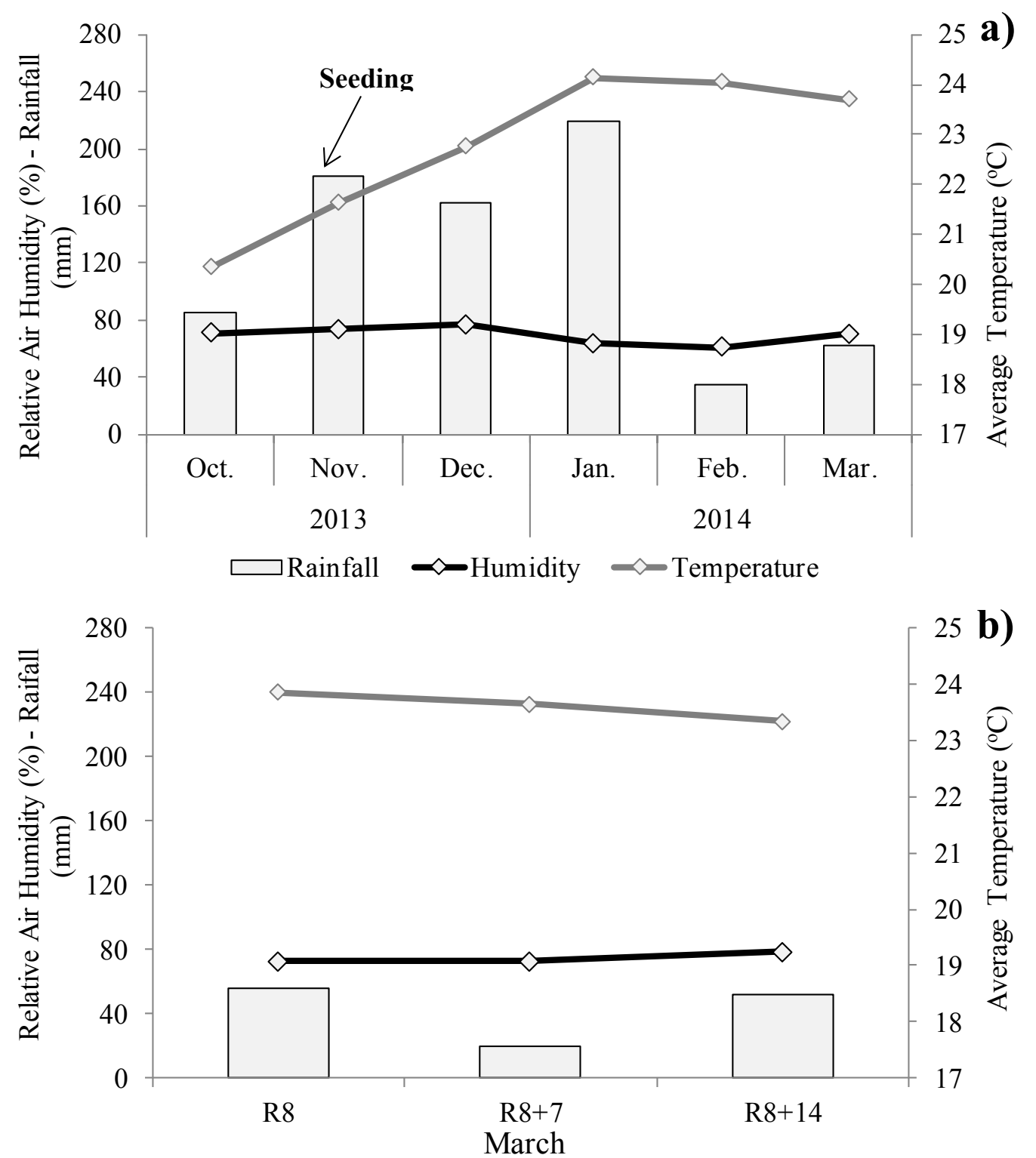

Figure 1. Monthly averages of rainfall, relative air humidity, and air temperature in Lavras-MG, in the 2013/2014 agricultural year, during the production of soybean seeds (a) and at seed harvest times (b). Source: National Institute of Meteorology (INMET).

\section{Applied treatments}

The experiment consisted of a randomized block design, arranged in a factorial scheme $(4 \times 3)$ +1 , with four replications. The first factor corresponded to four herbicides for desiccation (paraquat - $2 \mathrm{~L} \mathrm{ha}^{-1}$, ammonium glufosinate $-2 \mathrm{~L}^{-1}{ }^{-}$ ${ }^{1}$, diquat - $1.5 \mathrm{~L} \mathrm{ha}^{-1}$, and saflufenacil - $40 \mathrm{~g} \mathrm{ha}^{-1}$ ), applied at the phenological stage $\mathrm{R}_{7.1}$ - beginning of leaf yellowing) (degree of moisture: 65\%). The second factor was composed of three harvest times $\left[0,7\right.$, and 14 days after the phenological stage $R_{8}$ full maturation, according to Fehr et al. (1971)] and additional treatment (control, application of water only, and harvested at the $\mathrm{R}_{8}$ stage). The desiccants were applied using a motorized knapsack sprayer, coupled to a boom with four spraying tips (XR 110.02), at a volume of $200 \mathrm{~L} \mathrm{ha}^{-1}$.
Plants were manually harvested, and threshing was performed by the Maqtron $^{\circledR}$ Vencedora machine. Seeds were stored in 'Kraft' paper bags and dried in the shade until reaching 13\% moisture. After checking the adequate moisture content, samples were homogenized and sieved. Seeds retained in the $6.00 \mathrm{~mm}$ mesh sieves were used for analyses and determinations.

\section{Evaluated variables}

Thousand seeds weights (BRASIL, 2009) and yields (in $\mathrm{kg} \mathrm{ha}^{-1}$ of seeds) were determined, with the correction for $13 \%$ moisture. Seeds physiological qualities were evaluated by the following determinations:

Moisture content (MC): after drying, seeds 
had their water content determined as a percentage, according to Brasil (2009).

Emergence under controlled conditions (EMER): the substrate consisted of a soil + sand mixture (2:1 ratio), moistened with $70 \%$ of the retention capacity, and stored in plastic trays, with four replications of 50 seeds. The trays were kept in a greenhouse at $25^{\circ} \mathrm{C}$, according to the crop's needs. From the emergence of the first seedling (cotyledon above the ground), daily evaluations were carried out by counting the number of seedlings emerged until stabilization. The final count occurred at 14 days after sowing. The final mean emergence percentage $(\% \quad \mathrm{E})$ and the emergence speed index (ESI) determined by Maguire (1962) were also considered.

Plant total dry matter (TDM): after the stabilization of the emergence, all plants from each tray were collected and dried in a greenhouse at $60^{\circ}$ $\mathrm{C}$, for $72 \mathrm{~h}$. The dry matter was composed of the weight of all plants divided by the number of seeds sown (50 seeds) and expressed in milligrams.

Germination (GER): the seeds were distributed on germitest paper, moistened with a volume of distilled water equivalent to 2.5 times that of the non-hydrated paper, in the form of rolls. Treatments consisted of 50 seeds, with four replications. Afterwards, treatments were stored in a BOD chamber at $25^{\circ} \mathrm{C}$, and the number of germinated plants was counted at 8 days, according to Brasil (2009).

Electrical conductivity (EC): the mass conductivity method was applied, using 50 seeds per replication, previously weighed, placed in plastic cups containing $75 \mathrm{~mL}$ of deionized water, and kept at $25^{\circ} \mathrm{C}$ for $24 \mathrm{~h}$ (KRZYZANOWSKI; VIEIRA; FRANÇA NETO, 1999). At the end of this period, the containers were gently shaken, and the conductivity meter (MS TECNOPON ${ }^{\circledR}$ - mCA150) was used to measure the electrical conductivity readings of the solution, expressed in $\mu \mathrm{S} \mathrm{cm}^{-1} \mathrm{~g}^{-1}$.

Accelerated aging (AA): seeds were placed on a stainless steel screen adapted to Gerbox boxes $(11.0 \mathrm{~cm} \times 11.0 \mathrm{~cm} \times 3.0 \mathrm{~cm})$, containing $40 \mathrm{~mL}$ of water at the bottom. Then, the boxes containing the different treatments were closed and taken to a BOD chamber, at $41^{\circ} \mathrm{C}$, for $48 \mathrm{~h}$. Afterwards, the germination test was carried out as previously described, and the normal seedlings were counted at five days after sowing and evaluated according to Brasil (2009).

Enzymatic expression: seeds were ground in a cooled mill, with liquid nitrogen and PVP (polyvinylpyrrolidone). For the evaluation of each enzyme, $100 \mathrm{mg}$ of the ground material was used. Before extraction, samples were washed with ethyl ether and water to remove the oil, according to Carvalho et al. (2014a). Seeds were added with 300 $\mu \mathrm{L}$ of the extraction buffer, using Tris $\mathrm{HCl}$ buffer
(0.2 mol L $\left.\mathrm{L}^{-1}, \mathrm{pH} 8.0\right)$ and $0.1 \% \beta$-mercaptoethanol. The material was refrigerated for $12 \mathrm{~h}$ and then centrifuged at $18,000 \times \mathrm{g}$ for $30 \mathrm{~min}$ at $4^{\circ} \mathrm{C}$. The electrophoretic analyses were performed in a vertical electrophoresis system, model MV20COMP, at 150 $\mathrm{V}$, for 6 hours at $4^{\circ} \mathrm{C}$, while applying $60 \mu \mathrm{L}$ of the supernatant to the gel channel. Polyacrylamide gel electrophoresis (NAAPA-PAGE) was developed in a discontinuous system $(4.5 \%$ concentration gel and $7.5 \%$ separation gel). Tris-glycine gel, $\mathrm{pH} 8.9$, was used as gel/electrode buffer system. At the end of the electrophoretic analyses, the gels were developed for the isoenzymes malate dehydrogenase (EC 1.1.1.37; $\mathrm{MDH}$ ), alcohol dehydrogenase (EC 1.1.1.1; ADH), esterase (EC 3.1.1.1; EST), isocitrate lyase (EC 4.1. 3.1, ICL), and superoxide dismutase (EC 1.15.1.1; SOD), according to Alfenas (2006). The enzymatic profiles were evaluated according to the presence or absence of bands and their intensity.

\section{Statistical analyses}

The experiment was carried out in a completely randomized block design, arranged in a 4 $\times 3+1$ factorial scheme, with first factor four desiccant herbicides, second factor three harvest times after desiccation, and one additional treatment (with water application and harvest at the $\mathrm{R}_{8}$ stage) for both factors tested, with four blocks in the field. Data were subject to analysis of variance using the Sisvar $^{\circledR}$ version 5.3 software for Windows (Statistical Analysis Software, UFLA, Lavras, MG, BRA) (FERREIRA, 2011), by the F test at 5\% of probability, and means comparison, by the Tukey's test at $5 \%$ probability.

\section{RESULTS AND DISCUSSION}

The analysis of variance revealed significant effects for the desiccant products (D) $\times$ harvest times (T) interaction for germination test, electrical conductivity and accelerated aging (Table 2). The isolated effects showed significant statistical differences in function of the desiccant for germination test and total dry matter. These variables, as well as electrical conductivity, also had significant statistical differences for harvest times. In relation to the overall factorial mean, the control treatment (additional) showed significant effects only for germination, at the $5 \%$ probability (Table 2 ). Previous reports have shown the isolated effect caused by the harvest time delay on the soybean crop (XAVIER et al., 2015; ZUFFO et al., 2017a,b) and by the use of desiccants (MARCANDALLI; LAZARINI; MALASPINA, 2011; LAMEGO et al., 2013) as a management strategy. 
A. M. ZUFFO et al.

Table 2. Analysis of variance for the moisture content (MC) and germination test (GER), emergence (EMER), emergence speed index (ESI), total dry matter (TDM), electrical conductivity (EC), and accelerated aging (AA), obtained in the chemical desiccation test and harvest times of soybean (cv. BRS $820 \mathrm{RR}^{\circledR}$ ).

\begin{tabular}{lccccccc}
\hline \multirow{2}{*}{ Sources of variation } & \multicolumn{9}{c}{ Probability $>\mathrm{F}^{1}$} \\
\cline { 2 - 8 } & MC & GER & EMER & ESI & TDM & EC & AA \\
\hline Dissecants (D) & 0.137 & 0.033 & 0.548 & 0.466 & $<0.01$ & 0.207 & 0.251 \\
Harvest Time (T) & 0.948 & $<0.01$ & 0.249 & 0.157 & $<0.01$ & $<0.01$ & 0.164 \\
D x T & 0.806 & $<0.01$ & 0.641 & 0.436 & 0.127 & $<0.01$ & 0.046 \\
Factorial x additional & 0.398 & $<0.01$ & 0.411 & 0.210 & 0.352 & 0.275 & 0.146 \\
CV (\%) & 6.50 & 13.30 & 11.16 & 14.28 & 3.74 & 1.33 & 9.26 \\
\hline
\end{tabular}

${ }^{1}$ Fisher-Snedecor F test; CV - coefficient of variation.

The use of ammonium glufosinate and paraquat desiccant herbicides resulted in negative effects on the dry matter of the seedlings produced by the desiccated seeds. However, the use of diquat provided seedlings with higher dry matter accumulations. Means of seeds produced by saflufenacil desiccation did not differ from the others (Table 3), regardless of the harvest time. Thus, the choice and use of the appropriate desiccant product in seed production is fundamental. The additional treatment did not differ statistically from the overall mean for total dry matter (Table 3 ).

Table 3. Mean values of the variables that did not show significant interaction: moisture content (MC) and emergence tests (EMER), emergence speed index (ESI), total dry matter (TDM), obtained in the chemical desiccation test and harvest times of cv. BRS $820 \mathrm{RR}^{\circledR}$.

\begin{tabular}{ccccc}
\hline Desiccants & MC (\%) & $\begin{array}{c}\text { EMER } \\
(\%)\end{array}$ & $\begin{array}{c}\text { ESI } \\
(-)\end{array}$ & $\begin{array}{c}\text { TDM } \\
(\mathrm{mg})\end{array}$ \\
\hline Paraquat & $8.18^{\mathrm{ns}}$ & $88^{\mathrm{ns}}$ & $18.77^{\mathrm{ns}}$ & $214.29 \mathrm{~B}$ \\
Diquat & 7.81 & 92 & 19.78 & $264.35 \mathrm{~A}$ \\
Ammonium Glufosinate & 7.75 & 90 & 18.28 & $192.35 \mathrm{~B}$ \\
Saflufenacil & 7.63 & 86 & 17.43 & $231.15 \mathrm{AB}$ \\
\hline Harvest Time & & & & \\
\hline $\mathrm{R}_{8}$ & $7.82^{\mathrm{ns}}$ & $86^{\mathrm{ns}}$ & $18.57^{\mathrm{ns}}$ & $194.58 \mathrm{~B}$ \\
$\mathrm{R}_{8}+7$ & 7.83 & 87 & 18.57 & $265.27 \mathrm{~A}$ \\
$\mathrm{R}_{8}+14$ & 7.88 & 93 & 18.57 & $216.77 \mathrm{~B}$ \\
\hline Additional $^{1}$ & 7.58 & 84 & 17.22 & 206.33 \\
\hline
\end{tabular}

Means followed by the same uppercase letter in the column belong to the same group, by the ttest, at the $5 \%$ probability. ${ }^{1}$ Values for each characteristic in the two factors evaluated.

Significant $\mathrm{D} \times \mathrm{T}$ interactions were observed for the variables germination, electrical conductivity and accelerated aging (Table 2 and Table 4). For germination, all harvest times had differences between the types of desiccant herbicides. At the $\mathrm{R}_{8}$ stage, the lowest value was obtained with saflufenacil. At the $R_{8}+7$ stage, the lowest value was detected with ammonium glufosinate. Conversely, at the $\mathrm{R}_{8}+14$ stage, the highest value was reported with the use of diquat. In all harvest times, the use of diquat resulted in higher germination values than the other products. However, the germination mean was low (76\%). Results revealed that the desiccant chemicals influenced the physiological quality of the seeds by promoting significant variations in germination and total dry matter (Table 2). Conversely, Daltro et al. (2010) observed that paraquat, diquat, and the combinations of paraquat + diquat and paraquat + diuron did not influence the physiological quality of the seeds. For Botelho et al. (2016), ammonium glufosinate also had a negative effect on the quality of soybean seeds.
Significant $\mathrm{D} \times \mathrm{T}$ interactions were observed for the variables germination, electrical conductivity and accelerated aging (Table 2 and Table 4). For germination, all harvest times had differences between the types of desiccant herbicides. At the $\mathrm{R}_{8}$ stage, the lowest value was obtained with saflufenacil. At the $R_{8}+7$ stage, the lowest value was detected with ammonium glufosinate. Conversely, at the $\mathrm{R}_{8}+14$ stage, the highest value was reported with the use of diquat. In all harvest times, the use of diquat resulted in higher germination values than the other products. However, the germination mean was low (76\%). Results revealed that the desiccant chemicals influenced the physiological quality of the seeds by promoting significant variations in germination and total dry matter (Table 2). Conversely, Daltro et al. (2010) observed that paraquat, diquat, and the combinations of paraquat + diquat and paraquat + diuron did not influence the physiological quality of the seeds. For Botelho et al. (2016), ammonium glufosinate also had a negative effect on the quality of soybean seeds. 
A. M. ZUFFO et al.

Table 4. Mean values of germination, electrical conductivity and accelerated aging obtained for soybean seeds ('BRS 820 $\mathrm{RR}^{, \circledR}$ ) from the desiccation with different herbicides and different harvest times.

\begin{tabular}{|c|c|c|c|}
\hline \multirow{2}{*}{ Desiccants } & \multicolumn{3}{|c|}{ Germination (\%) } \\
\hline & $\mathrm{R}_{8}$ & $\mathrm{R}_{8}+7$ & $\mathrm{R}_{8}+14$ \\
\hline Paraquat & $70 \mathrm{Ab}$ & $89 \mathrm{Aa}$ & $54 \mathrm{Bb}$ \\
\hline Diquat & $74 \mathrm{Aa}$ & $80 \mathrm{Aba}$ & $74 \mathrm{Aa}$ \\
\hline Ammonium Glufosinate & $69 \mathrm{Aa}$ & $60 \mathrm{Ba}$ & $68 \mathrm{ABa}$ \\
\hline Saflufenacil & $49 \mathrm{Bb}$ & $75 \mathrm{Aba}$ & $70 \mathrm{ABa}$ \\
\hline \multirow{2}{*}{ Desiccants } & \multicolumn{3}{|c|}{ Electrical conductivity $\left(\mu \mathrm{S} \mathrm{cm}^{-1} \mathrm{~g}^{-1}\right)$} \\
\hline & $\mathrm{R}_{8}$ & $\mathrm{R}_{8}+7$ & $\mathrm{R}_{8}+14$ \\
\hline Paraquat & $90.33 \mathrm{Aa}$ & $115.00 \mathrm{Cb}$ & $88.57 \mathrm{Aa}$ \\
\hline Diquat & $91.27 \mathrm{Aa}$ & $96.59 \mathrm{Aba}$ & $87.95 \mathrm{Aa}$ \\
\hline Ammonium Glufosinate & 93.25 Aab & 104.14 BCb & $81.50 \mathrm{Aa}$ \\
\hline Saflufenacil & $102.56 \mathrm{Aa}$ & $83.93 \mathrm{Ab}$ & $86.32 \mathrm{Ab}$ \\
\hline \multirow{2}{*}{ Desiccants } & \multicolumn{3}{|c|}{ Accelerated aging (\%) } \\
\hline & $\mathrm{R}_{8}$ & $\mathrm{R}_{8}+7$ & $\mathrm{R}_{8}+14$ \\
\hline Paraquat & $66.33 \mathrm{Aa}$ & $65.66 \mathrm{Aa}$ & $33.66 \mathrm{Bb}$ \\
\hline Diquat & $47.00 \mathrm{Aa}$ & $64.00 \mathrm{Aa}$ & $47.00 \mathrm{ABa}$ \\
\hline Ammonium Glufosinate & $52.33 \mathrm{Aa}$ & $43.33 \mathrm{Aa}$ & $52.66 \mathrm{ABa}$ \\
\hline Saflufenacil & $63.00 \mathrm{Aa}$ & $58.00 \mathrm{Aa}$ & $62.33 \mathrm{Aa}$ \\
\hline
\end{tabular}

Means followed by the same lowercase letters in the same column and the same uppercase letter in the same row do not differ from each other by the Tukey's test at the $5 \%$ of probability.

For electrical conductivity, differences between the desiccant products were observed only for the harvest time $\mathrm{R}_{8}+7$, in which the highest values were found in seeds desiccated with paraquat and ammonium glufosinate, indicating possible damage to the plasma membranes and their permeability. Vieira and Krzyzanowski (1999) demonstrated that high-vigor soybean seeds should have electrical conductivity values lower than 70-80 $\mu \mathrm{S} \mathrm{cm}^{-1} \mathrm{~g}^{-1}$. Using this criterion as a quality standard, the combination of ammonium glufosinate (with an overall mean of $92.96 \mu \mathrm{S} \mathrm{cm}^{-1} \mathrm{~g}^{-1}$ ) and $\mathrm{R}_{8}+14$ (with an overall mean of $99.91 \mu \mathrm{S} \mathrm{cm}^{-1} \mathrm{~g}^{-1}$ ) resulted in the best seed quality, considering the lowest values obtained for this variable with an overall mean of $81.50 \mu \mathrm{S} \mathrm{cm}^{-1} \mathrm{~g}^{-1}$. The lowest mean performance (with the highest values of $115.00 \mu \mathrm{S} \mathrm{cm}^{-1} \mathrm{~g}^{-1}$ ) was obtained for the combination of paraquat (with an overall mean of $97.97 \mu \mathrm{S} \mathrm{cm}^{-1} \mathrm{~g}^{-1}$ ) and $\mathrm{R}_{8}+7$ (with an overall mean of $86.08 \mu \mathrm{S} \mathrm{cm}^{-1} \mathrm{~g}^{-1}$ ) (Table 5). Vargas and Roman (2006) consider paraquat a nonselective herbicide. The authors state that it is usually applied at the post-emergence stage, kills by contact, is characterized by a reduced translocation in the plant and a low persistence in the soil, and is used for total vegetation control. Kappes et al. (2009) compared paraquat with diquat and found that paraquat had a better performance in some of the quality tests carried out with cultivar 'M-SOY 8866 '. In the present study, this difference was found only at the $\mathrm{R}_{8}+7$ harvest time, and diquat provided better performance when considering electrical conductivity.

For the variable accelerated aging, only the use of paraquat provided differences in the harvest time. The ratio of the losses was inversely proportional to the harvest time. The most delayed harvest time had the most accelerated aging, showing a $50 \%$ decrease in vigor with 14 days of delay in harvest $\left(66.33 \%\right.$ in $R_{8}$ and $33.66 \%$ in $R_{8}+$ $14)$. For the same the variable, only for the $R_{8}+14$ harvest was there revealed a difference between the desiccants, in which paraquat caused the highest damage, being $33.66 \%$ for accelerated aging (Table 4).

The accelerated aging test quantifies the percentage of germinated plants after seeds have undergone a stress condition that caused seed deterioration and a lower germination rate (SANTOS et al., 2018). For this variable, only the combination of desiccants with harvest at $\mathrm{R}_{8}+14$ resulted in significant differences. The combination with saflufenacil (overall mean of $61.1 \%$ ) led to the lowest damages, with $62.33 \%$ accelerated aging. Paraquat (overall mean of $55.22 \%$ ) resulted in the highest damages, with $33.66 \%$ of accelerated aging. Santos et al. (2018), when evaluating paraquat + diquat in the desiccation of four soybean cultivars, reported that the use of desiccants negatively influenced the physiological quality of soybean seeds, except for cultivar 'BRS 7380 RR'.

The harvest time also influenced germination, total dry matter, electrical conductivity, and accelerated aging, as observed in previous studies (DINIZ et al., 2013; XAVIER et al., 2015). Harvesting after the ideal period $\left(\mathrm{R}_{8}\right)$ leads to the deterioration of seed physiological quality (MARCANDALLI; LAZARINI; MALASPINA, 2011) when considering the inhibition of germination. Delaying the seed harvest 10-15 days after the $R_{8}$ stage impairs vigor and germination, respectively (ZUFFO et al. 2017b). The lowest means were observed at $R_{8}$ and $R_{8}+14$ days. This fact is directly related to the climatic conditions at 
the harvest times, as shown in (Figure $1 \mathrm{~b}$ ), in which $\mathrm{R}_{8}$ and $\mathrm{R}_{8}+14$ days registered approximately $50 \mathrm{~mm}$ of rainfall, which depreciated the seed quality. The harvest time $\mathrm{R}_{8}+7$ days registered $20 \mathrm{~mm}$ of rainfall, which evidences the relevance of the climatic conditions on the quality, especially rainfall. For Gris et al. (2010), delaying the harvest in up to 20 days $\left(\mathrm{R}_{8}+20\right)$ reduced the values of seed germination and vigor.

When evaluating the additional treatment concerning the overall factorial means (Table 5), significant differences were found only for germination. The use of herbicides and harvest times (factorial) resulted in higher percentages of germination and moisture damage when compared with the additional treatment.

Table 5. Mean values of moisture content (MC) and germination (GER), emergence (EMER), emergence speed index (ESI), total dry matter (TDM), electrical conductivity (EC), accelerated aging (AA), obtained from soybean seeds ('BRS $820 \mathrm{RR}^{\text {, }}{ }^{\circledR}$ ) from the desiccation with different herbicides and different harvest times.

\begin{tabular}{lccccccc}
\hline Contrast & MC $(\%)$ & $\begin{array}{c}\text { GER } \\
(\%)\end{array}$ & EMER $(\%)$ & $\begin{array}{c}\text { ESI } \\
(-)\end{array}$ & $\begin{array}{c}\text { TDM } \\
(\mathrm{mg})\end{array}$ & $\begin{array}{c}\text { EC } \\
\left(\mu \mathrm{cm}^{-1} \mathrm{~g}^{-1}\right)\end{array}$ & AA (\%) \\
\hline Additional & 7.58 & $54.33 \mathrm{~b}$ & 17.22 & 17.22 & 206.33 & 88.53 & 65.66 \\
Factorial & 7.84 & $69.41 \mathrm{a}$ & 19.23 & 19.23 & 225.54 & 93.45 & 54.61 \\
\hline
\end{tabular}

${ }^{1} \mathrm{~F}$ test of Fisher-Snedecor; CV: coefficient of variation.

The expression of enzymes linked to respiration processes (alcohol dehydrogenase and malate dehydrogenase), lipid breakage (esterase and isocitrate lyase) and antioxidants (superoxide dismutase) were evaluated (Figure 2).

The expression of the enzyme alcohol dehydrogenase showed differences in function of the harvest time when using paraquat, ammonium glufosinate, and saflufenacil. With a 14-day harvest delay $\left(R_{8}+14\right)$, the expression was reduced (Figure 2a). Results showed differences in its enzymatic profile in function of the harvest time when using paraquat, ammonium glufosinate, and saflufenacil. The enzymatic expression decreased at $\mathrm{R}_{8}+14$ (Figure 2a). The relevance of this enzyme is given by its action on the anaerobic metabolism, with the conversion of acetaldehyde into ethanol. When the activity of this enzyme is low, the seed becomes more susceptible to the deleterious action of the acetaldehyde, which is more toxic than ethanol. The relation between the high expression of alcohol dehydrogenase and better seed physiological quality has been previously reported (CARVALHO et al., 2014a; CARVALHO et al., 2014b; ZUFFO et al. 2017a). Alcohol dehydrogenase expressions were more uniform when using diquat, and were maintained even at 14-days harvest delay $\left(\mathrm{R}_{8}+14\right.$ days). This fact contributed to the higher germination percentage obtained with diquat application, even with the harvest delay (Table 4), showing that this enzyme was efficient in monitoring and had an adequate correlation with the physiological quality.

No differences were detected for the enzyme malate dehydrogenase regarding the expression pattern in function of the different desiccant herbicides and harvest times. The patterns were similar to those observed in the control (Figure 2b). The enzyme malate dehydrogenase is essential in aerobic respiration, acting on the Krebs cycle. It is also fundamental for adenosine triphosphate (ATP) production (CARVALHO et al., 2014b), acting on the gluconeogenesis during germination (VIEIRA et al., 2013). However, in this study, this enzyme showed no variations correlated to the physiological behavior of the seeds. The low variation and sensitivity make this system inefficient in indicating small variations and relations with physiological quality. This low efficiency has been reported in studies with enzymatic expression in soybean seeds (CARVALHO et al., 2014b).

The expression of esterase decreased with the use of paraquat and the seven-day and 14-day harvest delays (Figure 2c). With the application of this product and the 14-day delay $\left(\mathrm{R}_{8}+14\right)$, both germination and accelerated aging vigor were lower in relation to the others (Table 4). This result contributed to the decrease in seeds physiological quality since this enzyme is involved in lipid degradation, which is an essential process for soybean seed germination (CARVALHO et al., 2014b). According to Ferreira (2015), the highest increase in esterase expression may be related to the higher germination values, as observed in germination and accelerated aging vigor. Harvest delay affects the seed physiological quality and the esterase expression. Vieira et al. (2013) also reported a relationship between the decrease in the esterase activity and the lower vigor of soybean seeds. The physiological problems, such as the decrease in the germination and accelerated aging vigor, were verified in physiological tests with 14-day harvest delay. Nevertheless, the lowest esterase expression had been previously reported at the seven-day harvest delay. The longer time the seeds remained in the field corresponded to a lower seed physiological quality and esterase expression (ZUFFO et al., 2017a). This fact shows the possibility of using enzymatic expressions to anticipate physiological problems. Lower expression was also observed when delaying the harvest by applying diquat and in the control, which, in general, showed low physiological quality. The use of this product and the 14-day 
harvest delay decreased the physiological quality, the germination, and the accelerated aging vigor. Therefore, enzymatic expressions can be used to infer about deleterious alterations at an early stage before the physiological effects.

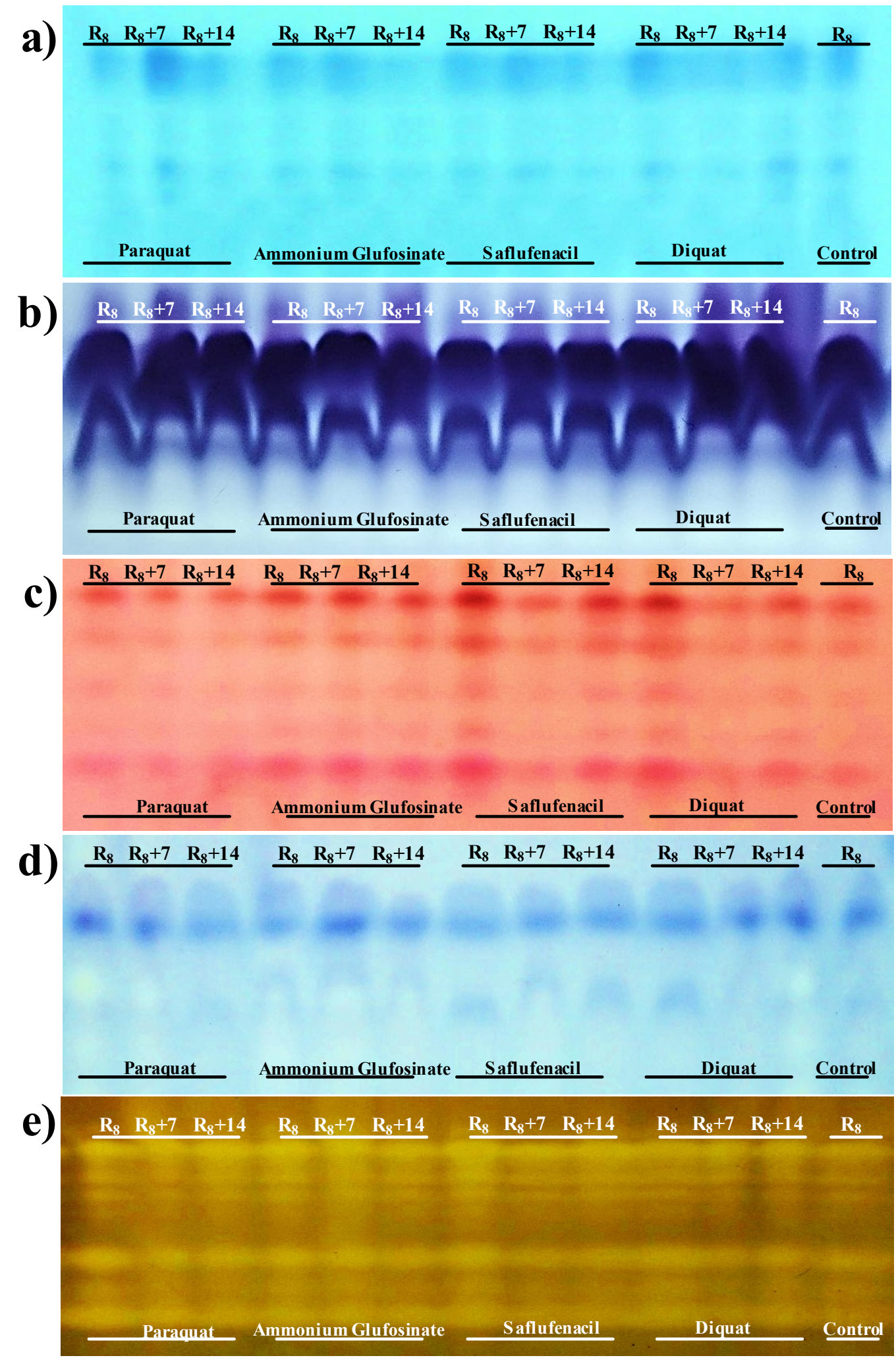

Figure 2. Expression of enzymes linked to respiration processes, lipid breakage and antioxidants. (a) Enzymes alcohol dehydrogenase, (b) malate dehydrogenase, (c) esterase, (d) isocitrate lyase, and (e) superoxide dismutase of soybean seeds produced with different desiccants (paraquat, ammonium glufosinate, saflufenac, and diquat) and different harvest times $\left(\mathrm{R}_{8}, \mathrm{R}_{8}+7\right.$, and $\left.\mathrm{R}_{8}+14\right)$. 
The enzymatic expression of isocitrate lyase showed consistent differences with the application of paraquat; the seven-day harvest delay decreased the activity, while the 14-day delay increased the activity (Figure 2d). This enzyme is relevant to oilseeds for acting in the glyoxylate cycle and glyoxysomes. It is also involved in the lipid metabolism by being part of the lipid degradation system (CARVALHO et al., 2014a). The lower activity of the isocitrate lyase enzyme corresponds to a lower conversion of lipids into sugars in soybean seeds (BOREK; KUBALA; KUBALA, 2013).

Therefore, the germination and/or emergence were affected, which influenced the lower seed quality at the 14-day harvest delay, as shown in the physiological tests (Table 3 and Table 4). These results are similar to those found by Zuffo et al. (2017a), who also observed a decrease in the isocitrate lyase activity and a reduction in the physiological quality of seeds at 15-day harvest delay.

Superoxide dismutase had no significant differences between the harvest times (Figure 2e). Superoxide dismutase showed lower expression with the application of diquat, which is probably due to the lesser stress caused by this product. Usually, under stress, this enzyme will show an increase in the enzymatic expressions of antioxidant systems due to the higher presence of reactive oxygen species. Nevertheless, if this situation persists, the damage may lead to a decrease in the activity of antioxidant enzymes (CARVALHO et al. 2014a). These enzymes are relevant for making part of the antioxidant system, such as superoxide dismutase and peroxidase. They act in the removal and reduction of reactive oxygen species reactive oxygen species, which can cause cell damage and affect seed quality (DEUNER et al., 2011; CARVALHO et al., 2014a).

\section{CONCLUSIONS}

The use of desiccants and harvest times affects the physiological quality of soybean seeds regarding germination, electrical conductivity and accelerated aging.

Seeds harvested at the $\mathrm{R}_{8}+14$ stage had the highest losses in seed quality. However, the rainfall is significant, and $50 \mathrm{~mm}$ is sufficient to deteriorate soybean seeds.

Diquat and paraquat led to the lowest and highest damages to the physiological quality of the seeds, respectively.

The expression of the enzymes alcohol dehydrogenase, esterase and isocitrate lyase are efficient in monitoring and is directly correlated with the physiological quality. Malate dehydrogenase and superoxide dismutase have no satisfactory relation with the physiological tests performed with soybean seeds.

\section{REFERENCES}

ALFENAS, A. C. Eletroforese e marcadores bioquímicos em plantas e microrganismos. 2 . ed. Viçosa, MG: UFV. 2006. 627 p.

BOREK, S.; KUBALA, S.; KUBALA, S. Diverse regulation by sucrose of enzymes involved in storage lipid breakdown in germinating lupin seeds. Acta Physiologiae Plantarum, 35: 2147-2156, 2013.

BOTELHO, F. J. E. et al. Qualidade de sementes de soja obtidas de diferentes cultivares submetidas à dessecação com diferentes herbicidas e épocas de aplicação. Revista Agro@mbiente, 10: 137-144, 2016.

BRASIL. Ministério da Agricultura, Pecuária e Abastecimento. Regras para análise de sementes, Brasília: MAPA/ACS, 2009. 395 p.

CARVALHO, E. R. et al. Alterações isoenzimáticas em sementes de cultivares de soja em diferentes condições de armazenamento. Pesquisa Agropecuária Brasileira, 49: 967-976, 2014a.

CARVALHO, E. R. et al. Enzyme activity in soybean seeds produced under foliar application of manganese. Ciência e Agrotecnologia, 38: 317-327, 2014b.

COMPANHIA NACIONAL DE ABASTECIMENTO - CONAB. Acompanhamento da safra brasileira: grãos, v. 7 Safra 2019/20 Quarto levantamento, Brasília. 2020. p. 1-104.

DALTRO, E. M. F. et al. Aplicação de dessecante em pré-colheita: efeito na qualidade fisiológica de sementes de soja. Revista Brasileira de Sementes, 32: 111-122, 2010.

DEUNER C. et al. Viabilidade e atividade antioxidante de sementes de genótipos de feijãomiúdo submetidos ao estresse salino. Revista Brasileira de Sementes, 33: 711-720, 2011.

DINIZ, F. O. et al. Qualidade fisiológica de sementes de soja de cultivares submetidas ao atraso de colheita e sua associação com a emergência de plântulas no campo. Journal of Seed Science, 35: 147-152, 2013.

EMPRESA BRASILEIRA DE PESQUISA AGROPECUÁRIA - EMBRAPA. Centro Nacional de Pesquisa de Solos. Sistema brasileiro de 
classificação de solos. 3. ed. Brasília, DF: Embrapa Solos, 2013. 353 p.

FEHR, W. R. et al. Stage of development descriptions for soybeans, Glycine max (L.) Merrill. Crop Science, 11: 929-931, 1971.

FERREIRA, D. F. Sisvar: a computer statistical analysis system. Ciência e Agrotecnologia, 35: 1039-1042, 2011.

FERREIRA, V. F. Adubação com potássio nas características agronômicas e na qualidade de sementes de soja. 2015. 105 f. Tese (Doutorado em Fitotecnia: Área de Concentração em Tecnologia de Sementes) - Universidade Federal de Lavras, Lavras, 2015.

GRIS, C. F. et al. Qualidade fisiológica e teor de lignina no tegumento de sementes de soja convencional e transgênica RR submetidas a diferentes épocas de colheita. Ciência e Agrotecnologia, 34: 374-381, 2010.

KAPPES, C. et al. Potencial fisiológico de sementes de soja dessecadas com Reglone e Gramoxone. Scientia Agrária, 10: 1-6, 2009.

KRZYZANOWSKI, F. C.; VIEIRA, R. D.; FRANÇA NETO, J. B. Vigor de sementes: conceitos e testes. Associação Brasileira de Tecnologia de Sementes, Comitê de Vigor de Sementes, Londrina, PR: Abrates, 1999. 218 p.

LAMEGO, F. P. et al. Dessecação pré-colheita e efeitos sobre a produtividade e qualidade fisiológica de sementes de soja. Planta Daninha, 31: 929-938. 2013.

LIMA, W. A. A. et al. Retardamento de colheita como método de diferenciação de genótipos de soja para qualidade de sementes. Revista Brasileira de Sementes, 29: 186-192, 2007.

MAGUIRE, J. D. Speed of germination-aid in selection and evaluation for seedling emergence and vigor. Crop Science, 2: 176-177, 1962.

MARCANDALLI, L. H.; LAZARINI, E.; MALASPINA, I. C. Épocas de aplicação de dessecantes na cultura da soja: qualidade fisiológica de sementes. Revista Brasileira de Sementes, 33: 241-250, 2011.

MOREANO, T. B. et al. Physical and physiological qualities of soybean seed as affected by processing and handling. Journal of Seed Science, 35: 466-477, 2013.
SANTOS, F. L. et al. A influência de dessecante na qualidade fisiológica de sementes de soja. Brazilian Journal of Biosystems Engineering, 12: 68-76, 2018.

VARGAS, L.; ROMAN, E. S. Resistência de plantas daninhas a herbicidas: conceitos, origem e evolução. Passo Fundo, RS: Embrapa Trigo, 2006. $22 \mathrm{p}$.

VIEIRA, B. G. T. L. et al. Biochemical alterations in soybean seeds with harvesting time and storage temperature. Journal of Food, Agriculture \& Environment, 11: 887-891, 2013.

VIEIRA, R. D.; KRZYZANOWSKI, F. C. Teste de condutividade elétrica. In: KRZYANOWSKI, F. C.; VIEIRA, R. D.; FRANÇA NETO, J. B. (eds.). Vigor de sementes: conceitos e testes. Londrina, PR: Abrates, 1999. v. 1, cap. 4, p. 1-26.

XAVIER, T. S. et al. Época de colheita na qualidade de sementes de genótipos de soja. Comunicata Scientiae, 6: 241-245, 2015.

ZUFFO, A. M. et al. Physiological and enzymatic changes in soybean seeds submitted to harvest delay. Pesquisa Agropecuária Tropical, 47: 488-496, 2017a.

ZUFFO, A. M. et al. Physiological and sanitary quality of soybean seeds harvested at different periods and submitted to storage. Pesquisa Agropecuária Tropical, 47: 312-320, $2017 \mathrm{~b}$. 